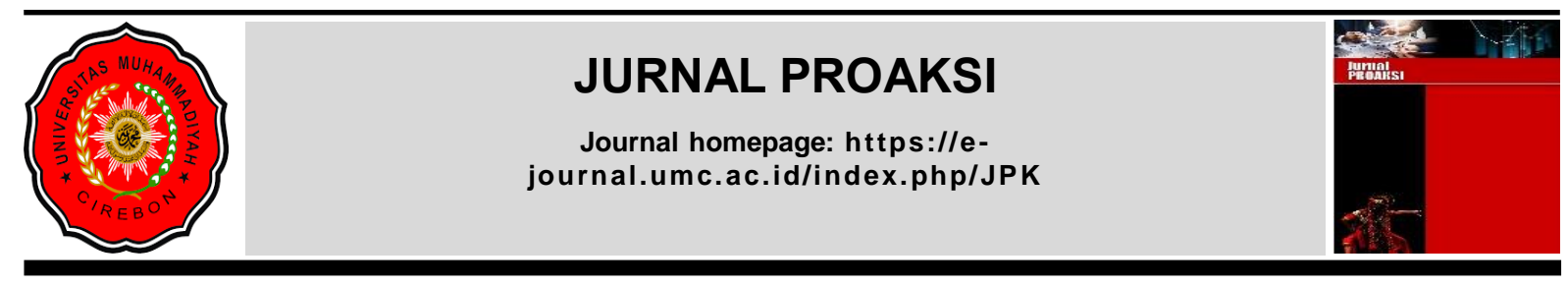

\title{
ANALISIS PENGARUH GENDER, MOTIVASI, DAN LITERASI KEUANGAN PADA SANDWICH GENERATION TERHADAP INTENSI BERINVESTASI
}

\author{
Yenny Ernitawati ${ }^{1}$ \\ Gian Fitralisma ${ }^{2}$ \\ ${ }^{1}$ Fakultas Ekonomi dan Bisnis, Universitas Muhadi Setiabudi \\ Email : yennyernitawati@gmail.com \\ ${ }^{2}$ Fakultas Ekonomi dan Bisnis, Universitas Muhadi Setiabudi \\ Email : fitralismagian@gmail.com
}

Diterima : 18 November 2021 Direvisi : 9 Desember 2021 Dipublikasikan : 30 Desember 2021

\begin{abstract}
Investment as early as possible for future funding needs is a way to break the chain of sandwich generation. A good investment must be equipped with a high investment intention. Many factors can maximize investment intentions, especially in relation to gender roles, one's motivation, and level of financial literacy. This study aims to analyze the effect of gender, motivation, on intention to invest UMKM. The dependent variable is intention to invest, the independent variable is gender and motivation. The population is all productive woman. Sampling in this study used purposive sampling technique. Valid sample of 181 was recruited in this study, and participants voluntarily answered online questionnaires. The analytical technique used is a structural equation model with the IBM Statistical Package for the Social Sciences version 25 application. The results show a significant positive effect between motivational variables and financial literacy on investment intentions. And the gender variable has no effect on investment intentions.).
\end{abstract}

Keywords: Gender, Motivation, Literacy, Intentions

\section{PENDAHULUAN}

Pada era saat ini investasi banyak diminati dan dilakukan oleh kalangan masyarakat usia produktif terutama oleh kaum perempuan. Investasi adalah peningkatan peran individu dalam aktivitas bisnis yang hasilnya berupa selisih lebih uang yang dapat digunakan untuk meningkatkan nilai asset dan kekayaan, untuk memenuhi kebutuhan yang direncanakan, instrument untuk melawan kenaikan harga di masa depan, serta ketidakpastian masa depan (Ernitawati et al., 2020).

Investasi di landasi oleh minat untuk berinvestasi yang dapat dijelaskan dari teori planned behaviour (Syarfi \& Asandimitra, 2020). Teori planned behaviour adalah model yang baik untuk menjelaskan niat seseorang untuk berinvestasi dan berinvestasi (Pascual-Ezama et al., 2014). Teori ini bertujuan mengetahui bagaimana seseorang bertindak yang dipengaruhi oleh tingkah laku, normatif subjektif serta pengendalian perilaku yang memerlukan perencanaan. Investasi dengan jaminan keamanan yang tinggi dan risiko yang rendah, adalah yang menjadi keinginan para penanam modal. Anggapan investor berinvestasi pada usaha mikro kecil dan menengah adalah mendapatkan keuntungan yang tinggi. Padahal untuk mendapatkan keuntungan yang tinggi calon investor harus mempunyai minat yang besar untuk berinvestasi dan memerlukan antara lain motivasi yang tinggi, literasi keuangan yang baik, dan peran gender yang harus di pertimbangkan.

Berkembangnya literasi keuangan di Indonesia membawa dampak kepada kehidupan masyarakat. Salah satunya adalah meningkatnya pengusaha wanita untuk Usaha Mikro Kecil dan Menengah (UMKM). Meningkatnya pengusaha Wanita akan membawa dampak luas untuk ekonomi rumah tangga dalam lingkup kecil. Dan untuk lingkup luas membawa dampak yang sangat signifikan, 
karena dapat meningkatkan taraf kesejahteraan di masyarakat. Karena literasi keuangan yang baik dapat memotivasi para investor pemula maka motivasi dijadikan sebagai variabel dalam penelitian ini untuk memperkuat dasar peningkatan minat berinvestasi pada usaha mikro kecil dan menengah.

Motivasi yang kuat mendorong terciptanya semangat tinggi untuk melakukan hal-hal menuju kemerdekaan finansial. Jika motivasi memudar akan mempengaruhi kemunduran dalam hal berusaha yang berakibat pada rendahnya tingkat kesejahteraan ekonomi pada keluarga di lingkup kecil. Upaya membangun kesetaraan gender telah dilakukan cukup lama, namun masih terdapat banyak hal dan sisi kehidupan yang belum mencerminkan adanya kesetaraan antara perempuan dan laki-laki. Kurangnya perhatian dan intensitas serta kesinambungan program pemberdayaan perempuan merupakan salah satu penyebab belum terciptanya kesetaraan gender (Marwanti \& Astuti, 2012). Pemberdayaan masyarakat khususnya perempuan adalah proses dimana perempuan yang kurang memiliki akses hasil dari kebijakan pemerintah, didorong untuk mandiri dalam rangka untuk mengembangkan taraf kehidupannya.

\section{KAJIAN PUSTAKA DAN PENGEMBANGAN HIPOTESIS}

\section{Intensi Investasi}

Minat adalah kecenderungan perasaan seseorang untuk membuat pilihan aktivitas, yang sifatnya dapat berubah atau tidak stabil karena faktor-faktor yang mempengaruhinya. Seseorang yang memiliki minat berinvestasi maka memiliki kecenderungan melakukan tindakan-tindakan yang dapat mendukung pencapaian keinginan untuk berinvestasi. Pernyatanyaan diatas juga didukung oleh penyataan dari (Hati \& Harefa, 2019) bahwa minat sangat besar pengaruhnya terhadap aktivitas yang dilakukan. Keadaan ini sesuai dengan Theory of Planned Behavior yang merupakan perluasan dari Theory of Reasoned Action yang menjadi dasar dari teori (Seni \& Ratnadi, 2017).

\section{Literasi Keuangan}

Literasi Keuangan menurut (Faidah, 2019) bahwa seseorang yang mempunyai pengetahuan tentang manajemen keuangan yang baik memiliki minat untuk melakukan investasi dan sebaliknya bagi seseorang yang kurang memiliki literasi keuangan tidak begitu berminat untuk melakukan investasi. Dengan literasi keuangan yang baik diharapkan mampu mendukung perencanaan keuangan personal dalam meningkatkan keterampilan membaca, menganalisis, dan mengelola keuangan sendiri, sehingga dapat menghindarkan dari permasalahan keuangan dalam keseharian (Gunardi et al., 2017). Dalam penelitian yang dilakukan oleh (Potrich et al., 2015) bahwa literasi keuangan mempunyai tiga dimensi yaitu sikap, keuangan, perilaku keuangan, dan pengetahuan keuangan.

\section{Motivasi}

Investor ternotivasi untuk berinvestasi dalam memenuhi kebutuhan diri, kebutuhan keluarga, kebutuhan untuk dapat mengaktualisasikan diri dimasyarakat untuk waktu yang lama. Menurut (Situmorang et al., 2014) motivasi adalah proses menjelaskan intensitas, arah, dan ketekunan seorang individu untuk mencapai tujuannya. Motivasi seseorang dalam berinvestasi sangat berpengaruh terhadap minat berinvestasi. Dengan tingginya motivasi yang dimiliki untuk berinvestasi, maka akan semakin kuat dan besar keinginan seseorang untuk berinvestasi (Amhalmad \& Irianto, 2019).

\section{Gender}

Serangkaian program pengembangan dan pelatihan dari sumber daya eksternal atau dari sumber daya masyarakat ditentukan oleh masyarakat, dimana lembaga pendukungnya hanya memiliki peran sebagai fasilitator (Sujarwo et al., 2017). Kelompok sasaran utama pemberdayaan perempuan ini adalah pelaku usaha Mikro Kecil dan Menengah (UMKM).

Pelaku UMKM yang dimaksud disini adalah tenaga yang membantu kegiatan di UMKM selain pemilik. Dalam proses pemberdayaan, masyarakat mendapatkan pembelajaran agar dapat secara mandiri melakukan upaya-upaya perbaikan kualitas kehidupannya (Saugi \& Sumarno, 2015). Wanita dan pria memiliki kondisi khusus yang berbeda, baik dari segi fisik maupun psikologis. Perbedaan tersebut merupakan sumber dari perbedaan fungsi dan peran yang diemban oleh wanita dan pria (Rahadjeng, 2011). Perempuan karena fisik biologisnya, seringkali tidak mendapatkan kesempatan untuk terlibat dalam hal akses kebutuhan spesifiknya. 


\section{PENGEMBANGAN HIPOTESIS}

\section{Pengaruh Gender terhadap Intensi Berinvestasi}

Gender adalah variabel penting yang perlu diperhatikan oleh masyarakat. Variabel ini berhubungan dengan pelibatan perempuan dalam memanfaatkan fasilitas yang ada disekitar untuk semakin berminat berinvestasi di UMKM. Beberapa peneliti telah menguji pengaruh gender terhadap intensi berinvestasi antara lain:(Yaasiin \& Sitanggang, 2020), Berdasarkan analisis diatas, maka peneliti mengajukan hipotesis sebagai berikut:

\section{H1: Gender berpengaruh positif terhadap Intensi berinvestasi}

\section{Pengaruh Motivasi terhadap Intensi Berinvestasi.}

Motivasi atau dorongan merupakan gerakan jiwa dan jasmani untuk berbuat, sehingga seseorang mendapatkan kekuatan untuk mencapai tujuan yang diinginkan (Atarwaman, 2014). Dalam berinvestasi, motivasi sangat diperlukan oleh seorang investor adalah motivasi dari dalam dirinya, dimana ketika seseorang ingin mengetahui hal baru dan ingin berubah maka akan memberikan dorongan dari dalam dirinya (Amhalmad \& Irianto, 2019). Beberapa peneliti telah menguji pengaruh motivasi untuk berinvestasi terhadap minat berinvestasi pada UMKM antara lain: (Hasanudin et al., 2021),(Hati \& Harefa, 2019), (Nisa \& Zulaika, 2017)mengemukakan bahwa motivasi seseorang untuk berinvestasi dapat menimbulkan minat yang kuat untuk berinvestasi pada UMKM. Berdasarkan penjelasan analisis diatas, maka peneliti mengajukan hipotesis sebagai berikut:

\section{H2: Motivasi berpengaruh positif terhadap Intensi berinvestasi}

\section{Pengaruh Literasi Keuangan terhadap Intensi Berinvestasi}

Literasi keuangan adalah kemampuan untuk membuat penilaian atas informasi keuangan dan untuk mengambil tindakan yang efektif dalam pengelolaan keuangan saat ini maupun di saat yang akan datang. Kemampuan untuk memahami portofolio keuangan, perencanaan masa depan, belanja dengan bijak (Purwidianti \& Tubastuvi, 2019). Individu yang akan merencanakan investasi, maka individu tersebut harus memiliki pengetahuan keuangan yang baik agar keputusan keuangannya memiliki tingkat risiko yang rendah. Literasi keuangan merupakan bagian dari pembelajaran dalam mengelola keuangan maupun perencanaan investasi sehingga dalam membuat keputusan keuangan setiap hari dapat lebih terarah dan lebih bijaksana(Putri \& Rahyuda, 2017). Beberapa peneliti telah menguji hubungan antara literasi keuangan dengan minat berinvestasi antara lain:(Faidah, 2019), (Yaasiin \& Sitanggang, 2020), (Pangestika \& Rusliati, 2019) menerangkan bahwa literasi keuangan dapat meningkatkan minat seseorang untuk berinvestasi pada UMKM. Berdasarkan penjelasan analisis diatas maka peneliti mengajukan hipotesis sebagai berikut:

\section{H3: Literasi Keuangan berpengaruh positif terhadap Intensi berinvestasi.}

Adapun kerangka pemikiran digambarkan dalam diagram berikut:

Gambar 1 Kerangka Pemikiran

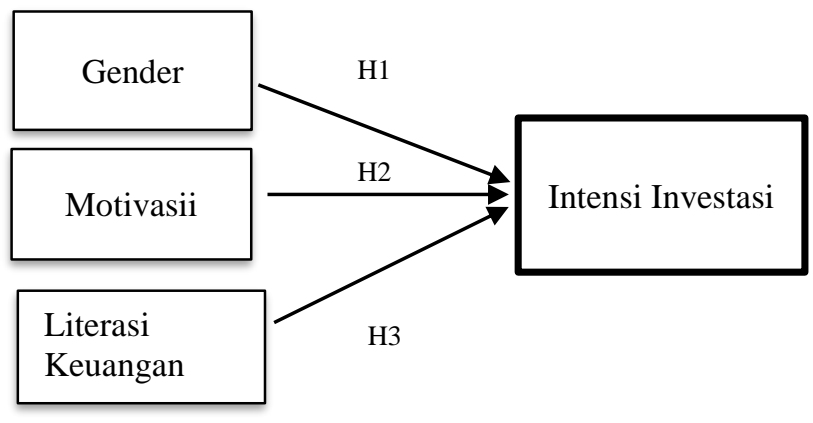

\section{METODE PENELITIAN}

Populasi dan sampel penelitian ini adalah Usaha Mikro Kecil dan Menengah (UMKM) yang berada di Kabupaten Brebes bagian barat tepatnya di wilayah Kecamatan Wanasari, Kecamatan Tanjung, Kecamatan Losari, dan Kecamatan Bulakamba. Jenis data yang digunakan adalah data primer yang diperoleh langsung dari hasil kuesioner yang diberikan kepada responden. Kuesioner yang 
dibagikan kepada responden menggunakan kuesioner yang tertutup dengan alasan untuk mempermudah responden dalam memberikan pendapat terbatasnya.

Metode pengambilan sampelnya menggunakan teknik purposive sampling. Purposive sampling adalah teknik pengambilan sampel dengan pertimbangan dan kriteria tertentu yang telah ditentukan sebagai berikut. Pertama, untuk ukuran perusahaan adalah Usaha Mikro Kecil dan Menengah. Kedua, pelaku usaha adalah perempuan. Ketiga, usia responden adalah usia produktif pada umur 15 tahun hingga 65 tahun. Keempat, lama usaha minimal satu (1) tahun. Kelima, pendidikan minimal SMA/SMK/MA/Sederajat. Untuk kuesioner yang dibagikan kepada responden, skala jawaban responden untuk penelitian ini menggunakan skala Likert dengan lima pilihan skala. Dan didapat hasil akhir dari sampel yang memenuhi kriteria yaitu sebanyak 181 responden.

Penelitian ini menggunakan metode kuantitatif dengan analisa regresi berganda (multiple regression), karena akan mengukur pengaruh tiga variabel bebas yaitu gender (X1), motivasi (X2), dan literasi keuangan (X3) dan satu variabel terikat yaitu Intensi Berinvestasi (Y). Pengujian H1, H2, dan H3 menggunakan analisis regresi berganda yaitu yang digunakan untuk menjelaskan pengaruh variabel bebas terhadap variabel terikat. Fungsi lain dari analisis regresi adalah untuk memprediksi suatu model sudah ditentukan. Berikut persamaan regresi yang dibentuk:

$$
Y=a+b_{1} X_{1}+b_{2} X_{2}+b_{3} X_{3}
$$

$$
\begin{array}{ll}
\text { Keterangan: } \\
\mathrm{Y} \quad=\text { Intensi Berinvestasi } \\
\alpha & =\text { Konstanta } \\
\mathrm{b}_{1} & =\text { Koefisien regresi untuk X1 } \\
\mathrm{b} 2 & =\text { Koefisien regresi untuk X2 } \\
\mathrm{b} 3 & =\text { Koefisien regresi untuk X3 } \\
\mathrm{X} 1 & =\text { Gender } \\
\mathrm{X} 2 & =\text { Motivasi } \\
\mathrm{X} 3 & =\text { Literasi Keuangan }
\end{array}
$$

\begin{tabular}{|c|c|c|c|}
\hline Variabel & Sig (2 Tailed) & Pearson Correlation & Keterangan \\
\hline GEN1 & 0,000 & 0,795 & Valid \\
\hline GEN2 & 0,000 & 0,757 & Valid \\
\hline GEN3 & 0,000 & 0,833 & Valid \\
\hline GEN4 & 0,000 & 0,800 & Valid \\
\hline GENS & 0,000 & 0,767 & Valid \\
\hline GEN6 & 0,000 & 0,802 & Valid \\
\hline GEN7 & 0,000 & 0,360 & Valid \\
\hline MOT1 & 0,000 & 0,738 & Valid \\
\hline MOT2 & 0,000 & 0,689 & Valid \\
\hline MOT3 & 0,000 & 0,797 & Valid \\
\hline MOT4 & 0,000 & 0,737 & Valid \\
\hline LIK 1 & 0,000 & 0,727 & Valid \\
\hline LIK2 & 0,000 & 0,690 & Valid \\
\hline LIK 3 & 0,000 & 0,760 & Valid \\
\hline LIK 4 & 0,000 & 0,468 & Valid \\
\hline LIKS & 0,000 & 0,526 & Valid \\
\hline LIK 6 & 0,000 & 0,732 & Valid \\
\hline LIK 7 & 0,000 & 0,761 & Valid \\
\hline LIKS & 0,000 & 0,773 & Valid \\
\hline LIK9 & 0,000 & 0,708 & Valid \\
\hline LIK 10 & 0,000 & 0,542 & Valid \\
\hline LIK 11 & 0,000 & 0,651 & Valid \\
\hline LIK 12 & 0,000 & 0,703 & Valid \\
\hline $\operatorname{LIK} 13$ & 0,000 & 0,725 & Valid \\
\hline STASI1 & 0,000 & 0,684 & Valid \\
\hline STASI2 & 0,000 & 0,765 & Valid \\
\hline STASI3 & 0,000 & 0,714 & Valid \\
\hline STASI4 & 0,000 & 0,696 & Valid \\
\hline
\end{tabular}

\section{HASIL DAN PEMBAHASAN}

\section{Hasil Analisis}

Tabel 1.

Hasil Uji Validitas

Sumber: Data diolah (2021) 


\section{Uji Validitas}

Validitas menunjukkan derajat ketepatan antara data yang sesungguhnya terjadi pada obyek dengan data yang dikumpulkan oleh peneliti (Sugiyono, 2014). Uji validitas ini diperoleh dari kuesioner, dengan menggunakan korelasi Pearson Product Moment yaitu korelasi antar item dengan skor total dalam satu variabel, dengan menggunakan software SPSS 25 dengan tingkat signifikansi $(\alpha)$ $=0,05$ karena dianggap dapat mewakili untuk penelitian ilmu sosial. Jumlah sampel $(n)=181$ responden, sehingga diperoleh $\mathrm{r}$ tabel sebesar 0,145. Berdasarkan pada tabel 1 diketahui bahwa nilai signifikansi ( 2 tailed) dibawah dari 0,05 dan nilai Pearson Corellation lebih besar dari nilai $\mathrm{T}$ hitung yaitu diatas 0,145 , maka data dinyatakan valid.

\section{Uji Reliabilitas}

Reliabilitas adalah tingkat keterpercayaan, keterandalan, konsistensi, atau kestabilan hasil pengukuran (Indrawati, 2015). Menurut (Sugiyono, 2014), instrument dikatakan reliabel jika koefisien reabilitasnya minimal 0,6 . Dan data yang penulis olah menunjukkan semua variabelnya reliabel karena $\alpha$ lebih besar dari 0,6 .

Tabel 2

Hasil Uji Reliabilitas

\begin{tabular}{llcc}
\hline \multicolumn{1}{c}{ Variabel } & \multicolumn{1}{c}{ Jumlah Item } & Nilai Alpha Crombacl & Keterangan \\
\hline Gender & 7 pertanyaan & 0,849 & Reliabel \\
Motivasi & 4 pertanyaan & 0,678 & Reliabel \\
Literasi Keuangan & 13 pertanyaan & 0,898 & Reliabel \\
Intensi Berinvestasi & 4 pertanyaan & 0,667 & Reliabel \\
\hline
\end{tabular}

Sumber: Data Diolah, tahun 2021

\section{Uji Normalitas}

Uji ini bertujuan untuk menguji variabel bebas dan variabel terikat, apakah terdistribusi normal atau tidak normal pada persamaan regresi yang dihasilkan.

Tabel 3.

Hasil Uji Normalitas

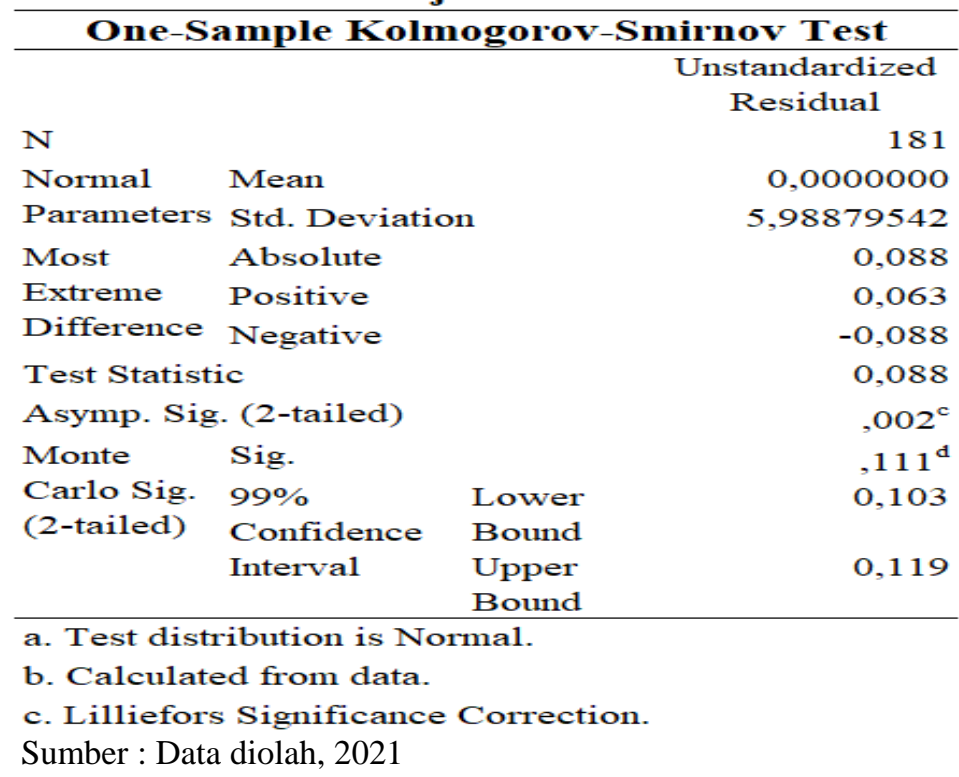

Berdasarkan tabel 3, data diatas telah diuji menggunakan Kolmogorov-Smirnov, dengan menentukan kriteria yang salah satu hasil dapat dilihat dari nilai Monte Carlo Sig (2 tailed) yang lebih besar dari 0,05 . Hasil tersebut dapat disimpulkan bahwa data yang digunakan terdistribusi dengan normal. 


\section{Uji Multikolinearitas}

Uji Multikolinearitas merupakan pengujian yang bertujuan untuk mengetahui korelasi antar variabel dalam model regresi. Untuk medeteksi ada tidaknya multikolinearitas adalah dengan menggunakan Variance Inflation Factors(VIF). Dengan bantuan software SPSS 25 diperoleh hasil:

\begin{tabular}{|c|c|c|c|}
\hline \multicolumn{4}{|c|}{$\begin{array}{c}\text { Tabel } 4 \\
\text { Hasil Uji Multikolinearitas }\end{array}$} \\
\hline \multirow{5}{*}{ Model } & & \multicolumn{2}{|c|}{$\begin{array}{c}\text { Coefficients }^{\mathbf{a}} \\
\text { Collinearity Statistics }\end{array}$} \\
\hline & & Tolerance & VIF \\
\hline & $\begin{array}{l}\text { (Constant) } \\
\text { gender }\end{array}$ & 0,545 & 1,836 \\
\hline & motivasi & 0,545 & 1,836 \\
\hline & $\begin{array}{l}\text { literasi } \\
\text { keuangan }\end{array}$ & 0,545 & 1,836 \\
\hline
\end{tabular}

Sumber: Data diolah,2021

Hasil diatas menjelaskan bahwa nilai VIF kurang dari 10 dan nilai Tolerance lebih besar dari 0,100, sehingga dapat disimpulkan tidak terdapat gangguan multikolinearitas pada data.

\section{Uji Heterokedastisitas}

Uji ini digunakan untuk menguji model regresi linear karena ketidaksamaan varian dari residual satu amatan ke amatan lain.

\begin{tabular}{|c|c|c|c|c|c|c|}
\hline \multicolumn{7}{|c|}{$\begin{array}{c}\text { Tabel } 5 \\
\text { Hasil Uji Heterokedastisitas } \\
\text { Correlations } \\
\end{array}$} \\
\hline & & & IST Res & Gender & Motivasi & $\begin{array}{l}\text { Literasi } \\
\text { Keuangan }\end{array}$ \\
\hline \multirow{11}{*}{$\begin{array}{l}\text { Spear } \\
\text { man's } \\
\text { rho }\end{array}$} & AbsRes & $\begin{array}{l}\text { Correlation } \\
\text { Coefficient }\end{array}$ & 1,000 & $.259^{* *}$ & 0,024 & $-0,067$ \\
\hline & & Sig. (2-tailed) & & 0,074 & 0,747 & 0,373 \\
\hline & & $\mathrm{N}$ & 181 & 181 & 181 & 181 \\
\hline & Gender & $\begin{array}{l}\text { Correlation } \\
\text { Coefficient }\end{array}$ & $.259^{\text {n* }}$ & & $-0,137$ & $.693^{n x}$ \\
\hline & & Sig. (2-tailed) & 0,063 & & 0,066 & 0.068 \\
\hline & & $\mathrm{N}$ & 181 & 181 & 181 & 181 \\
\hline & Motivasi & $\begin{array}{l}\text { Correlation } \\
\text { Coefficient }\end{array}$ & 0,024 & $-0,137$ & 1,000 & $-0,099$ \\
\hline & & Sig. (2-tailed) & 0,747 & 0,066 & & 0,183 \\
\hline & & $N$ & 181 & 181 & 181 & 181 \\
\hline & $\begin{array}{l}\text { Literasi } \\
\text { keuanga }\end{array}$ & $\begin{array}{l}\text { Correlation } \\
\text { Coefficient }\end{array}$ & $-0,067$ & $.693^{* *}$ & $-0,099$ & 1,000 \\
\hline & n & Sig. (2-tailed) & $\begin{array}{r}0,373 \\
181\end{array}$ & $\begin{array}{r}0.81 \\
181\end{array}$ & $\begin{array}{r}0,183 \\
181\end{array}$ & 181 \\
\hline
\end{tabular}

Sumber: data diolah (2021)

Dari hasil pengujian didapatkan nilai signifikansi lebih besar dari tingkat signifikansinya $(0,05)$ untuk variabel gender, motivasi, literasi keuangan dan AbsRes (Y') maka H0 diterima atau tidak terjadi masalah heterokedastisitas.

\section{Uji Autokorelasi}

Model regresi yang baik adalah bebas dari gejala autokorelasi. Salah satu cara untuk mendeteksi autokorelasi adalah dengan uji Durbin Watson. Uji Durbin Watson memiliki ketentuan sebagai dasar pengambilan keputusan yaitu:

1. Jika d lebih kecil dari dl atau lebih besar dari (40dl), maka hipotesis ditolak.

2. Jika d terletak diantara dU dan (4-dU), maka hipotesis nol diterima. 
3. Jika d terletak antara dL dan dU atau diantara (4-dU) dan (4-dL), maka tidak menghasilkan kesimpulan yang pasti.

Hasil pengujian menunjukkan bahwa nilai Durbin Watson (d) sebesar 1,965 lebih besar dari batas atas(dU) yakni 1,7910 dan kurang dari (4-dU) yakni 4-1,7910=2,209. Maka dapat disimpulkan bahwa tidak terdapat masalah atau gejala autokorelasi, dan analisis regresi untuk uji hipotesis dapat dilanjutkan.

\section{Tabel 6}

Uji Autokorelasi

\begin{tabular}{|c|c|c|c|c|c|}
\hline \multicolumn{6}{|c|}{ Model Summary ${ }^{\mathbf{b}}$} \\
\hline Model & $\mathrm{R}$ & R Square & $\begin{array}{c}\text { Adjusted R } \\
\text { Square }\end{array}$ & $\begin{array}{l}\text { Std. Error } \\
\text { of the } \\
\text { Estimate }\end{array}$ & $\begin{array}{l}\text { Durbin- } \\
\text { Watson }\end{array}$ \\
\hline & $.090^{\mathrm{a}}$ & 0,008 & $-0,009$ & 0,90981 & 1,965 \\
\hline
\end{tabular}

a. Predictors: (Constant), Literasi Keuangan, Motivasi, Gender

b. Dependent Variable: Intensi Investasi

Sumber : data diolah (2021)

\section{Uji T}

Uji t umumnya digunakan untuk pengujian hipotesis. Berdasarkan tabel 7 dari ketiga variabel independent yang berpengaruh secara signifikan terhadap intensi berinvestasi adalah variabel motivasi dan variabel literasi keuangan.

\begin{tabular}{|c|c|c|c|c|c|c|}
\hline & & & $\begin{array}{r}\text { Tabel } \\
\text { Uji } T \\
\text { Coefficie }\end{array}$ & $t^{a}{ }^{a}$ & & \\
\hline \multirow[b]{2}{*}{ Model } & & \multicolumn{2}{|c|}{$\begin{array}{l}\text { Unstandardized } \\
\text { Coefficients }\end{array}$} & $\begin{array}{c}\text { Standardized } \\
\text { Coefficients }\end{array}$ & \multirow[b]{2}{*}{$t$} & \multirow[b]{2}{*}{ Sig. } \\
\hline & & $\mathrm{B}$ & Std. Error & Beta & & \\
\hline 1 & (Constant) & 5,961 & 0,741 & & 109,355 & 0,000 \\
\hline & Gender & 0,022 & 0,020 & 0,113 & 1,110 & 0,269 \\
\hline & Motivasi & 0,026 & 0,001 & 0,983 & 41,756 & 0,000 \\
\hline & $\begin{array}{l}\text { Literasi } \\
\text { Keuangan }\end{array}$ & 0,001 & 0,001 & 0,038 & 1,997 & 0,049 \\
\hline
\end{tabular}

a. Dependent Variable: Intensi Investasi

Sumber: data diolah (2021)

\section{PEMBAHASAN}

\section{Pengaruh gender terhadap intensi berinvestasi.}

Hipotesis pertama, dikatakan bahwa gender memiliki pengaruh positif terhadap intensi berinvestasi pada usaha mikro kecil dan menengah. Nilai signifikansi yang diperoleh dari pengolahan data untuk pengaruh antara variabel gender terhadap intensi berinvestasi pada UMKM mempunyai nilai diatas batas toleransi kesalahan sehingga dapat disimpulkan hipotesis satu tidak diterima. Jadi semakin kuat tingkat kesetaraan gender tidak akan mempengaruhi intensi berinvestasi seseorang untuk menanamkan modalnya pada usaha mikro kecil dan menengah. Hasil penelitian ini mendukung beberapa penelitian yang berkaitan dengan pengaruh gender terhadap intensi berinvestasi antara lain: (Timothius Tandio \& A. A. G. P. Widanaputra, 2016), (Yaasiin \& Sitanggang, 2020), (Trihudiyatmanto, 2019) yang menyimpulkan bahwa gender tidak berpengaruh terhadap intensi berinvestasi pada UMKM.

\section{Pengaruh motivasi terhadap intensi berinvestasi.}

Hipotesis kedua, dikatakan bahwa motivasi dapat mempengaruhi minat seseorang untuk berintensi investasi pada UMKM. Hasil dari pengujian menunjukkan tingkat signifikansi kurang dari tingkat signifikansi yang ditentukan. Semakin besar motivasi seseorang untuk untuk meningkatkan kesejahteraan maka akan semakin tinggi minat berinvestasi seseorang pada UMKM. Dengan demikian penelitian ini mendukung hipotesis bahwa motivasi mempengaruhi seseorang untuk berintensi investasi. Penelitian yang mendukung hipotesis ini antara lain: (Pangestika \& Rusliati, 2019), (Nisa \& 
Zulaika, 2017), yang menyatakan bahwa motivasi dapat mempengaruhi intensi berinvestasi seseorang pada UMKM.

\section{Pengaruh literasi keuangan terhadap intensi berinvestasi.}

Hipotesis ketiga, dikatakan bahwa literasi keuangan berpengaruh positif pada intensi berinvestasi. Semakin luas pemahaman keuangan seseorang terhadap tingkat return dan risiko keuangan maka akan semakin meningkatkan intensi seseorang dalam berinvestasi di UMKM. Dengan adanya hasil uji $t$ yang dilihat dari tingkat signifikansi yang mencapai lebih kecil dari tingkat yang signifikansi yang ditentukan maka hipotesis tiga dapat diterima. Penelitian ini didukung oleh penelitian terdahulu antara lain: (Faidah, 2019), (Yaasiin \& Sitanggang, 2020), (Pangestika \& Rusliati, 2019), yang menyatakan bahwa tingkat litersi yang luas dapat mempengaruhi intensi seseorang untuk berinvestasi di sektor UMKM.

\section{KESIMPULAN}

Berdasarkan hasil dan pembahasan diatas, maka dapat diambil beberapa kesimpulan sebagai berikut. Pertama, gender tidak berpengaruh terhadap intensi berinvestasi di UMKM, yang dapat diartikan bahwa minat untuk berinvestasi dapat tumbuh dari banyak faktor yang mempengaruhi dan tidak terbatas dilakukan oleh perempuan ataupun laki-laki. Kedua, motivasi berpengaruh positif terhadap intensi berinvestasi di UMKM, yang dapat diartikan bahwa intensi berinvestasi yang tinggi dikarenakan motivasi yang kuat yang ada pada diri perempuan. Ketiga, literasi keuangan berpengaruh positif terhadap intensi berinvestasi di UMKM. Temuan ini mengindikasikan bahwa persepsi menjadi investor pada UMKM membutuhkan motivasi yang kuat untuk membantu para pelaku UMKM dapat bertahan, bertumbuh di tengah kondisi ekonomi yang tidak menentu. Berdasarkan hal tersebut maka dapat disimpulkan bahwa motivasi yang tinggi akan memutus rantai sandwich generation dan tingkat literasi mengenai investasi yang baik bereaksi terhadap tingkat intensi seseorang untuk berinvestasi. Dengan kata lain, penelitian ini mengkonfirmasi theory of planned behavior.

\section{SARAN}

\section{Saran Praktis :}

1. Melakukan sinergitas dengan Pemerintah Daerah Kabupaten Brebes. Hal ini dapat dilakukan dengan membuat program pelatihan Bersama yang dapat meningkatkan motivasi perempuan untuk dapat mengembangkan potensi daerahnya sebagai sarana untuk berwirausaha dengan mengutamakan kearifan lokal. Peran perempuan disini dapat berupa sebagai investor dan dapat juga sebagai pelaku usaha di sektor UMKM.

2. Merencanakan dan melaksanakan program pelatihan bersama secara lebih komprehensif yang dimulai dari tahap perencanaan pelatihan, pemilihan lokasi pelatihan, pelaksanaan dan memanfaatkan materi pelatihan guna peningkatan minat berinvestasi atau bahkan menjadi investor ataupun pelaku UMKM.

\section{Saran Teoritis :}

1. Secara teoritis untuk teori Planned Behavior sebaiknya di sandingkan dengan theory of reasoned action sehingga lebih memperkuat kajian terhadap variabel dependen yaitu variabel intensi berinvestasi.

2. Saran untuk penelitian selanjutnya yaitu memperluas sampel penelitian dibeberapa kelompok masyarakat di usia produktif. Penelitian selanjutnya diharapkan menambah variabel lain yang mungkin berpengaruh terhadap intensi berinvestasi pada Usaha Mikro Kecil dan Menengah (UMKM). Pada uji t variabel literasi keuangan hanya kecil mempengaruhi intensi berinvestasi, sehingga penelitian selanjutnya diharapkan dapat menggunakan variabel lain yang belum diteliti ataupun menambah jumlah variabel penelitian.

\section{REFERENSI}

Amhalmad, I., \& Irianto, A. (2019). Pengaruh Pengetahuan Investasi dan Motivasi Investasi Terhadap Minat Berinvestasi Mahasiswa Pendidikan Ekonomi Fakultas Ekonomi Universitas Negeri Padang. Jurnal EcoGen, 2(4), 734-746.

Atarwaman, R. J. D. (2014). Motivasi Kualitas, Motivasi Karier dan Motivasi Ekonomi Terhadap Minat Mahasiswa Akuntansi (S1) Untuk Mengikuti Pendidikan Profesi Akuntansi (PPAK). Jurnal Analisis Bisnis Ekonomi, 12(1), 82-96. 
Ernitawati, Y., Nurul Izzati, \& Andi Yulianto. (2020). Pengaruh Literasi Keuangan dan Pelatihan Pasar Modal Terhadap Pengambilan Keputusan Investasi. Jurnal Proaksi, 7(2), 66-81. https://ejournal.umc.ac.id/index.php/JPK/article/view/1273

Faidah, F. (2019). Pengaruh Literasi Keuangan dan Faktor Demografi Terhadap Minat Investasi Mahasiswa. Journal of Applied Business and Economic, 5(3), 251-263.

Gunardi, A., Ridwan, M., \& Gugum Mukdas Sudarjah. (2017). The Use of Financial Literacy for Growing Personal Finance. Jurnal Keuangan dan Perbankan, 21(3), 446-458.

Hasanudin, H., Nurwulandari, A., \& Safitri, R. K. (2021). Pengaruh Pengetahuan Investasi, Motivasi Investasi dan Pelatihan Pasar Modal Terhadap Keputusan Investasi Yang Dimediasi Oleh Minat Investasi. Jurnal Ilmiah Manajemen Ekonomi \& Akuntansi, 5(3), 494-512. https://doi.org/https://doi.org/10.31955/mea.vol5.iss3.pp494-512

Hati, S. W., \& Harefa, W. S. (2019). Analisis Faktor-Faktor Yang Mempengaruhi Minat Berinvestasi di Pasar Modal Bagi Generasi Milenial (Studi Pada Mahasiswi Jurusan Manajemen Bisnis Politeknik Batam). Journal of Business Administration, 3(2), 281-295.

Indrawati. (2015). Metode Penelitian Manajemen dan Bisnis Konvergensi Teknologi Komunikasi dan Informasi. Aditama.

Marwanti, S., \& Astuti, I. D. (2012). Model Pemberdayaan Perempuan Miskin Melalui Pengembangan Kewirausahaan Keluarga Menuju Ekonomi Kreatif di Kabupaten Karanganyar. Jurnal Sosial Ekonomi Pertanian dan Agribisnis, 9(1). https://doi.org/https://doi.org/10.20961/sepa.v9i1.48814

Nisa, A., \& Zulaika, L. (2017). Pengaruh Pemahaman Investasi, Modal Minimal Investasi, dan Motivasi Terhadap Minat Mahasiswa Berinvestasi di Pasar modal. PETA, 2(2), 22-35.

Pangestika, T., \& Rusliati, E. (2019). Literasi dan Efikasi Keuangan Terhadap Minat Mahasiswa Berinvestasi di Pasar Modal. Jurnal Riset Bisnis dan Manajemen, 12(1), 37-42.

Pascual-Ezama, D., Scandroglio, B., \& Gil-Gomez de Liaño, B. (2014). Can we predict individual investors' behavior in stock markets? A psychological approach. Universitas Psychologica, 13(1). https://doi.org/10.11144/Javeriana.UPSY13-1.cwpi

Potrich, A. C. G., Vieira, Kelmara Mendes, Kirch, \& Guilherme. (2015). Determinants of Financial Literacy: Socioeconomic and Demographic Variables. R.Con.Fin.-USP, 26(69), 362-377.

Purwidianti, W., \& Tubastuvi, N. (2019). The Effect of Financial Literacy and Financial Experience on SME Financial Behavior in Indonesia. Jurnal Dinamika Manajemen, 10(1), 40-45. https://doi.org/DOI: 10.15294/jdm.v10i1.16937

Putri, N. M. D. R., \& Rahyuda, H. (2017). Pengaruh Tingkat Financial Literacy Dan Faktor Sosiodemografi Terhadap Perilaku Keputusan Investasi Individu. E-Jurnal Ekonomi dan Bisnis Universitas Udayana, 9, 3407. https://doi.org/10.24843/eeb.2017.v06.i09.p09

Rahadjeng, E. R. (2011). Analisis Perilaku Investor Perspektif Gender Dalam Pengambilan Keputusan Investasi di Pasar Modal. HUMANITY, 6(2), 90-97.

Saugi, W., \& Sumarno, S. (2015). Pemberdayaan perempuan melalui pelatihan pengolahan bahan pangan lokal. Jurnal Pendidikan dan Pemberdayaan Masyarakat, 2(2), 226. https://doi.org/10.21831/jppm.v2i2.6361

Seni, N. N. A., \& Ratnadi, N. M. D. (2017). Theory of Planned Behavior untuk Memprediksi Niat Berinvestasi. E-Jurnal Ekonomi dan Bisnis Universitas Udayana, 6, 4043-4068.

Situmorang, M., Andreas, \& Natariasari, R. (2014). Pengaruh Motivasi Terhadap Minat Berinvestasi di Pasar Modal Dengan Pemahaman Investasi dan Usia Sebagai Variabel Moderat. JOM FEKON, 1(2).

Sugiyono. (2014). Metode Penelitian Pendidikan Pendekatan Kuantitatif, Kualitatif, dan $R \& D$. ALfabeta.

Sujarwo, S., Tristanti, T., \& Santi, F. U. (2017). Pengembangan Model Pemberdayaan Perempuan Desa Wisata Melalui Pendidikan Berbasi Komunitas. JURNAL PENELITIAN ILMU PENDIDIKAN, 10(1), 75. https://doi.org/10.21831/jpipfip.v10i1.16798

Syarfi, S. M., \& Asandimitra, N. (2020). Implementasi Theory of Planned Behaviour dan Risk Tolerance Terhadap Intensi Investasi Peer To Peer Lending. Jurnal Ilmu Manajemen, Jurusan Manajemen Fakultas Ekonomi Universitas Negeri Surabaya, 8(3). 
Jurnal Proaksi, Vol. 8 (2), Hal. 611 - 620

Timothius Tandio, \& A. A. G. P. Widanaputra. (2016). Pengaruh Pelatihan Pasar Modal, Return, Persepsi Risiko, Gender dan Kemajuan Teknologi Pada Minat Investasi Mahasiswa. E-Jurnal Akuntansi Universitas Udayana , 16, 2316-2341.

Trihudiyatmanto, M. (2019). Membangun Minat Berwirausaha Mahasiswa Dengan Pengaruh Faktor ECommerce, Pengetahuan Kewirausahaan, dan Gender. Jurnal Penelitian dan Pengabdian Kepada Masyarakat Unsiq, 6(2), 93-103. https://doi.org/DOI: https://doi.org/10.32699/ppkm.v6i2.678

Yaasiin, F. N., \& Sitanggang, T. N. (2020). Pengaruh Pengetahuan Investasi, Fasilitas Teknologi, Status Mahasiswa dan Gender Terhadap Minat Investasi Mahasiswa Universitas Prima Indonesia di Pasar Modal. Jurnal Mutiara Akuntansi, 5(2). 